\title{
ヒト胚ゲノム編集に関する 日本の法技術的課題
}

高山佳奈子

\section{問題の所在}

刑事法学を専門分野とする筆者は、2017年か らの日本学術会議第 24 期科学者委員会に設置さ れた「ゲノム編集技術に関する分科会」で、副委 員長として提言「ゲノム編集技術のヒト胚等へ の臨床応用に対する法規制のあり方について」 （2020年3月27日）の発出にかかわった。また、 これに先立ち、2018年11月に報告された中国 でのゲノム編集受精卵からの双生児の誕生を受 けて発出された「『ゲノム編集による子ども』の 誕生についての日本学術会議幹事会声明」(2018 年12月7日）の準備段階で、同分科会の武田洋 幸委員長 (第二部幹事) を通じて意見を述べる機 会を得た。

本稿では、筆者が科学技術・学術審議会（文 部科学省）や厚生科学審議会（厚生労働省）で ヒト肧等を用いた研究のあり方を検討してきた 経験もふまえ、日本におけるヒト胚等（生殖細 胞や受精卵も含む）のゲノム改変の法規制にあ たって重要となる観点を示したい。なお筆者の 基本的な立場は、上記幹事会声明と「ゲノム編 集技術に関する分科会」提言との間に公刊され た高山佳奈子「ヒト胚の遺伝子改変をめぐる国 際的なルールメーキング」法学セミナー 2019年 7月 (774) 号33-39頁に示している。

\section{「法律」による規制の欠如}

中国で起きたような遺伝子操作によるヒトの 形質の変更については、もともと法律で禁止し ていた国もあれば、事件後に法改正を行って対 応した国もある。最近では、本特集の他の論考 で言及されるようにフランスの法改正において 議論があったほか、中国では新たに成立した民 法でも規制が定められるに至った。現在のとこ ろ、「法律」の形式でヒトの遺伝的形質の操作を 規制していない国は、技術面でこれが行われる 現実的可能性を有する国の中では相対的に少数 である（詳しくは「ゲノム編集技術に関する分科 会」提言を参照)。

日本では、中国の事案で用いられたとされる CRISPR-Cas（クリスパー・キャス）技術が報告 された 2013年よりもはるかに前の 2002年から、 政府の「遺伝子治療等臨床研究に関する指針」が 「人の生殖細胞又は胚 $(\cdots . . . \cdot)$ の遺伝的改変を目 的とした遺伝子治療等臨床研究及び人の生殖細 胞又は胚の遺伝的改変をもたらすおそれのある 遺伝子治療等臨床研究は、行ってはならない」 としていた。中国の事案を受け、禁止を明確化 する趣旨で文言が改正された同指針が2019年4 月 1 日に施行された (第 1 章第 7$)$ 。

「法律」の形式をとっていなくても、行政指針 で明確なルールが定められているのであれば実 


\section{PROFILE}

高山佳奈子 (たかやま かた)

日本学術会議第一部会員

曰京都大学大学院法学研究科教授

専門 刑事法学

質的な相違はないのではないか、という見方も、 法律家以外においては多くみられる。しかし多 数の国が「法律」を制定していることにはいくつ かの理由がある。一つは民主主義の要請である。 研究の自由や職業の自由、病気を克服する権利、 家族を形成する権利などを制限するには根拠が 必要であり、不明点の多いリスクが存在すると きに国としていかなる政策を採用するかは民主 的決定によらなければならない。誰がいつどの ような理由で決定を下したのかについて、責任 の所在が明らかであることによって初めて、内 容の合理性も担保される。もう一つは規制の実 効性の要請である。コロナウイルス対策におい て明らかになったように、行政的な規制しか行 われていない場合、強制的な措置や刑事誩の賦 課はできず、違反事案の公表のみが可能である (リンチが生じる可能性はある)。

ルールの内容について見ても、複数の利害が 対立している領域で、どのような利益衡量がな された結果どのような規制が決定されたのかが 透明でなければ、前提となる事実的知見に変化 が生じたときにいかなる見直しが必要であるの かの検討は困難である。確かに現在のところ、 ヒト胚の取扱いに関する審議会では、基礎研究 のみが検討対象となっているので、議事録「黒 塗り」現象は起きていない。しかし、個人情報 や営業秘密が扱われる審議会では詳細な議事録 が非公開となりうるから、臨床応用に近づけば 近づくほど政策決定過程が不透明になることは 構造的に問題である。国会の場で、要点が明示 され、記録が改ざんされずに公表されることが
必要である。

この必要性を示す例として、生殖につながら ない基礎研究における、ヒト胚等ゲノム編集の 取扱いの変化が挙げられる。政府は、生殖補助 医療に資する目的の基礎研究のみに㧍いて、生 殖補助医療の過程で生じた「余剩肧」にゲノム編 集技術を用いることを認める「ヒト受精肧に遺 伝情報改変技術等を用いる研究に関する倫理指 針」を2019年4月 1 に施行した。次いで、総合 科学技術・イノベーション会議が、生殖補助医 療に資する基礎研究だけでなく遺伝子疾患の克 服を目指す基礎研究も許容する方針の、「『ヒト 肧の取扱いに関する基本的考え方』見直し等に 係る報告 (第二次) 〜ヒト受精胚へのゲノム編集 技術等の利用等について〜」を同年6月19日に 公表している。もともと何がどのレベルで禁止 されることになっていたのか、また、指針がど のような前提の変化と検討に基づいて変更され たのかは、専門家が見ても必ずしも透明でない 部分が多い。生命の誕生や救助を左右しうる重 要な問題について、責任のある民主的な決定が 求められている（高山佳奈子「先端科学技術の刑 事的規制」法律時報 81巻5（1008）号 24頁以下 (2009) 参照)。

\section{民主的決定と責任の所在}

新たな科学技術の実践のように、前例がなく、 リスクの見積もりが確実でない行為を法的にど のように規制すべきかについては、主に環境規 制を念頭に「予防原則」が支持されるようになっ 
ている。国連環境開発会議が1992年の地球サ ミットで発出した「環境と開発に関するリオ宣 言」第15原則によれば、「環境を保護するため、 予防的方策は、各国により、その能力に応じて 広く適用されなければならない。媣刻な、ある いは不可逆的な被害のおそれがある場合には、 完全な科学的確実性の欠如が、環境悪化を防止 するための費用対効果の大きい対策を延期する 理由として使われてはならない」(政府訳)。つ まり、「確実なデータがないから規制しない」、 という発想ではなく、「確実なデータがなくても 安全策を講じる」方針が求められる。

ただし、リスクを完全にゼロにすることはで きないから、どこかで責任のある政策決定が下 されなければならない。望ましい「熟議民主主 義」のあり方としては、まず専門家が、判断資 料とすべき科学的知見をできる限り開示し、民 主的議論のために提供しなければならない。そ こに登用される専門家は一般市民の選挙で任命 されるわけではないが、情報と知見を開示する 責任を負う。これに反することは、民主主義を 瓦解させる「大罪」であるともいえる。

次いで、正しく開示された情報をもとに、民 主主義的な議論を経て政策が決定される。意見 がまとまらなければ最終的には多数決による。 その責任は立法者と有権者にある。事後に新た な知見が得られた場合には、政策を随時見直す ことが必要である。

法律を欠くということは、こうした舵取りが 民主的に行われていないことを意味する。

また、生存権や、病気の克服・家族形成を含
む幸福追求権、学問と職業の自由といった個人 の基本的人権を制約することとなる法規制は、 「法律」の形式をとって民主的に設けられなけれ ばならないという「法律の留保」の原則がある。 これは、法学研究者の間では理念としては共有 されてきたものの、本稿が扱っている領域はもっ ぱら行政指針によって規制されており、理念と 現実とが乘離している。

\section{日本法における政策形成}

政策の内容自体について見ると、後代に影響 しうるヒトの遺伝的形質の操作については、全 面的な否定論も全面的な肯定論も存在する。前 者は、自然に任せられるべき遺伝的形質の決定 を人為的に操作することについて、人の尊厳や 宗教的戒律を侵す、あるいは、人類にもたらし うるリスクがゼロでない、という理由で禁止し ようとする立場である。しかし、それは日本の 法制度に整合しない。日本では母体の健康が害 されるおそれのある場合に人工妊娠中絶が認め られている。これには、胎児に重篤な遺伝病が あるためにそうなるケースも含まれる。そうす ると、いったん妊娠してからの中絶という事態 を避けるため、限定的な範囲で、着床前診断に よって遺伝子を選別することも認めざるをえな い。日本では、胎児はまだ「人」ではないことが 民法でも刑法でも明示されている。それ以前の 胚や受精卵も「人」ではない。外国の憲法や特定 の宗教を援用して受精卵や胚を「人」と同視する 見解は、日本法の解釈論としては採用が難しい。 
他方、後者の立場は、病気を克服して命を守 る治療措置である点は遺伝子操作も変わるとこ ろがないとし、どこにも被害者のいない医療を 禁止する理由はないという。だが、法制上、被 害者となりうるのは、現に生きているヒトだけ ではない。環境保護のための諸法が前提とする ように、法律は、将来の人類をも保護すべく設 計される必要がある。

一般化して述べれば、日本の法制度は、人々 の行動を統制する際に利益衡量の手法を用いて おり、衡量する利益の中には将来世代の人類の 保護も含むのである。遺伝的情報を操作する者 の学問の自由や職業の自由も重要だが、本稿で は紙幅の制約から、潜在的な「被害者」を保護す る利益について論じる。

\section{個体の安全性}

1997年に発表されたクローン羊ドリーの誕生 を受けた議論を経て、日本で 2000 年にクローン 技術規制法が制定された際、クローン技術のヒ トへの応用を犯罪として処罰すること自体には あまり異論がなかったが、その理由としてはさ まざまな観点が挙げられ、同法第 1 条の目的規 定も複数の解釈の余地があるものになっている。 立法当時有力であった見解の一つは、クローン 技術はそれが施される客体に健康被害のおそれ をもたらすという安全性の問題を重視するもの であった。冒頭に挙げたゲノム編集にかかる幹 事会声明もこの点に第一に言及している。

確かに、個体の生命および身体は、日本法上、
保護されるべき最も重要な利益であるから、こ れらに対するリスクは規制されねばならない。 だが、個体の安全性は問題の一側面にすぎない。 クローン技術やゲノム編集技術の安全性が確立 すればクローン人間やいわゆる「デザイナーベ ビー」をいくらでも産生させてよい、というこ とにはならない。

他方、ゲノム編集によって救える命もあると いうことは、ゲノム編集の禁止によって、救え るはずの命を救わない、あるいは生まれること のできる命を誕生させない、という、生命軽視 を意味しないだろうか。たとえば、一つだけの 遺伝子によって起きる単一遺伝子疾患は、着床 前診断によっても排除できるが、受精卵の数を 確保できない場合には選別の実施が困難である。 遺伝子の特定の部分を変えてしまえば当該疾患 を排除できる。新たな技術の使用を禁止するこ とが、救える命を救わないという「不作為」を意 味しうることは、認識される必要がある。

\section{人類の持続可能性}

しかし、個体の安全性が確保されればゲノム 編集技術を多用して少子化対策に役立てるべき だ、といった議論が直ちに成り立つわけではな い。今回「ゲノム編集技術に関する分科会」の提 言が重視したのも、個体の保護を超えた人類全 体への影響であった。

ベトナムやインドでは、女性差別が根強いた め、男女産み分けによって新生览の人口比率に 不均衡が生じている。国民が男性ばかりになれ 
ば国は滅びるであろう。遺伝子の選別が人類の 多様性を損なうこととなれば、人類の存続に影 響するのである。

法制度は持続可能性を実現するものでなけれ ばならない。換言すれば、人類の存続を危うく するような法制度は認められない。法制度の究 極の、あるいは最低限の目的は、人類の存続で あると言ってもよい。

クローン技術やゲノム編集技術が、特定の遺 伝的形質の選択ないし排除を意味するとき、そ の蓄積は種としての人類の存続に影響を及ぼし うる。ここでは、環境保護法分野で採用されて いるように、リスクの累積が重大な結果をもた らしうるときには、単一の行為が持つリスクは 小さくても、当該リスク自体を規制する必要が あるという考え方の立法政策が求められる（高 山佳奈子「将来世代の法益と人間の尊厳」町野朔 先生古稀記念論文集上巻 (2014) 5頁以下)。

特定の遺伝的形質の選択ないし排除は、「優生 主義」や「ゲノム差別」を意味する。どのような 遺伝性疾患があろうとも、人間の価值は平等で ある。フランス法でクローン人間やデザイナー ベビーを誕生させようとする行為が人類に対す る重罪だと考えられているのは、ナチスによる ユダヤ人やマイノリティの迫害・虐殺に通ずる ものがあるからである。

しかし、現状では、重篤な遺伝性疾患の一定 のケースで、着床前診断や妊娠中絶を必要悪と して認めざるを得ない。

\section{法規制の課題と展望}

したがって、ヒト胚等ゲノム編集規制の内容 上のポイントは、人類全体の保護の観点からこ れを原則的に禁止する必要があるが、なお例外 を許容する余地を論じなければならない、とい うことである。幸いなことに、現時点で、国際 的な議論もその方向に収斂しつつあるように見 える。

日本でも、行政指針のレベルではあるが、「人 の生命の萌芽たる胚を改変することは悪」、「一 般人の間でコンセンサスが形成されるまで新技 術は使用させない」とするかつて有力であった 一方的な議論は約 20 年かけてようやく克服され つつある。政策形成はより分析的で合理的でな ければならない。日本では、憲法が受精卵や胚 に人の尊厳を認めているわけではなく、生命で あっても利益衡量の対象たりうるのである。リ スクを完全にゼロにはできないとき、小さすぎ るリスクを回避するために生命などの大きな価 值を失ってしまうことは政策として望ましくな い。たとえば天然痘の克服は、天然痘ウイルス の遺伝子を失わせることで種の多様性を害する が、天然痘から生命を守る利益の大きさに比べ れば、人類の存続のために冒してよいリスクで ある。ゲノム編集技術によって特定の遺伝的形 質を排除すると、それと同時に何か人類にとっ て有益なものが失われるかもしれない。しかし それが、天然痘ウイルスの担っていた種の多様 性程度のものであれば、その衰失は冒してよい リスクである。このような発想で「法律」の原則 
を示し、個別の政策を具体化すべきである。

現在日本では、臨床に至らないヒト胚等ゲノ 么編集の基礎研究を一定範囲で認める「指針」の 改訂が進められており、そこでの検討方法自体 は、リスク評価と利益衡量を重視する本稿の立 場と整合的である。民主的プロセスではなく専 門性によって立法過程への関与が認められる審 議会等の委員には、全体としての多様性と、可 能な限りの知見の開示が求められる。未解明の リスクにどのように対処するか。たとえば、す でに外国では、ミトコンドリア置換による一部 の遺伝子の改変の扱いが論じられている。夫婦 以外の第三者も当事者となるこうしたケースで は、自然科学的問題のほかに、家族関係の問題 も生じる。専門家らは、最新の知見を提供する 義務を負い、立法者には民主的な政策決定を「法 律」の形で示す義務がある。特定の技術の応用 を進めることにも止めることにも、責任は生じ うる。

追記：日本学術会議近畿地区会議は 2020 年 9 月 22 日に公開学術講演会「未来の語り 口：人間は神になれるか」をオンライン で開催した。法学・政治学分野からの講 演はなかったものの、環境学、情報学、 農学、科学哲学、社会学などの専門の見 地から、「将来の人類の立場をふまえた 政策立案」の方法が具体的に考察された。 本稿は民主主義的な決定の理念を抽象的 に論じたにすぎないが、今後は、それに 至るプロセスにおける検討の内容および
技術を科学的に提示していくことが研究 者の課題である。この問題にかかわる各 講演者の研究業績を参考資料として挙げ たい（講演者および演題は日本学術会議 ウェブサイト中の「一般公開イベント」 に掲載されている。http://www.scj.go.jp/ ja/event/2020/293-s-0922.html)。 